\title{
Low-cost fermentative medium for biosurfactant production by probiotic bacteria
}

\author{
L.R. Rodrigues*, J.A. Teixeira, R. Oliveira \\ Centro de Engenharia Biológica, Universidade do Minho, Campus de Gualtar, 4710-057 Braga, Portugal \\ Received 21 September 2005; received in revised form 2 June 2006; accepted 22 September 2006
}

\begin{abstract}
Potential use of alternative fermentative medium for biosurfactant production by Lactococcus lactis 53 and Streptococcus thermophilus A was studied. Suitable models were established to describe the response of the experiments pertaining to glucose, lactose or sucrose consumption, cell growth and biosurfactant production. Synthetic media MRS and M17 broth were used as control experiments. When the synthetic media were replaced by cheaper alternative media, as cheese whey and molasses, fermentations were carried out effectively with high yields and productivities of biosurfactant. An increase about 1.2-1.5 times in the mass of produced biosurfactant per gram cell dry weight and 60-80\% medium preparation costs reduction were achieved, for both strains.

In conclusion, the results obtained showed that supplemented cheese whey and molasses media can be used as a relatively inexpensive and economical alternative to synthetic media for biosurfactant production by probiotic bacteria, thus an attractive alternative as many of the potential applications for biosurfactants depend on whether they can be produced economically.
\end{abstract}

(C) 2006 Elsevier B.V. All rights reserved.

Keywords: Biosurfactant; Probiotic bacteria; Low-cost fermentative medium

\section{Introduction}

The interest in biosurfactants has increased considerably in recent years, as they are potential candidates for many commercial applications in the petroleum, pharmaceuticals, biomedical and food processing industries [1]. The biosurfactants have several advantages over chemical surfactants including lower toxicity and higher biodegradability, and effectiveness at extreme temperatures or $\mathrm{pH}$ values [2,3]. In spite of the advantages, fermentation must be cost competitive with chemical synthesis, and many of the potential applications that have been considered for biosurfactants depend on whether they can be produced economically. Fermentation medium can represent almost $30 \%$ of the cost for a microbial fermentation [4-6]. Complex media commonly employed for growth of lactic acid bacteria are not economically attractive due to their high amount of expensive nutrients such as yeast extract, peptone and salts $[5,7,8]$. Nevertheless, much effort in process optimization and at the

\footnotetext{
* Corresponding author at: Centro de Engenharia Biológica, IBQF, Universidade do Minho, Largo do Paço, 4719 Braga Codex, Portugal. Tel.: +351 253 604400; fax: +351 253678986

E-mail address: 1rmr@deb.uminho.pt (L.R. Rodrigues).
}

engineering and biological levels has been done, and for some applications biosurfactants can be produced from several inexpensive waste substrates, thereby decreasing their production cost [6,9-14].

Biosurfactant production by probiotic strains, Lactococcus lactis 53 and Streptococcus thermophilus A, using conventional synthetic media and its applications was reported previously [15-17]. Rodrigues et al. [18] optimized the medium components by response surface optimization for the production of biosurfactants by probiotic bacteria and concluded that it was possible to determine optimal operating conditions to obtain a higher cellular growth, thus a higher biosurfactant production yield. Moreover, the authors suggested that since both bacterial strains studied shown higher amounts of biosurfactant produced with the optimized medium, it would be possible to develop strategies for biosurfactant production from whey. In another study [19] suitable kinetic models were established for several Lactobacillus strains biosurfactant producers using whey as an alternative medium. A great variety of alternative raw materials is currently available as nutrients for industrial fermentations, namely various agricultural and industrial by-products and waste materials. A good substrate for biosurfactant production is whey, as it is composed of high levels of lactose, protein, organic acids and vitamins. Whey is a waste product from cheese production 


\begin{tabular}{|c|c|}
\hline \multicolumn{2}{|c|}{ Nomenclature } \\
\hline$F$ value & $F$ test statistical parameter \\
\hline$P$ & biosurfactant concentration $(\mathrm{g} / \mathrm{L})$ \\
\hline$P_{\max }$ & maximum concentration of biosurfactant $(\mathrm{g} / \mathrm{L})$ \\
\hline$P_{\mathrm{r}}$ & $\begin{array}{l}\text { ratio between initial volumetric rate of biosurfac- } \\
\text { tant formation }\left(r_{\mathrm{p}}\right) \text { and initial biosurfactant con- } \\
\text { centration } P_{0}\left(\mathrm{~h}^{-1}\right)\end{array}$ \\
\hline$P_{0}$ & initial biosurfactant concentration $(\mathrm{g} / \mathrm{L})$ \\
\hline$r_{\mathrm{p}}$ & $\begin{array}{l}\text { initial volumetric rate of biosurfactant production } \\
(\mathrm{g} /(\mathrm{L} h))\end{array}$ \\
\hline$r^{2}$ & correlation coefficient \\
\hline$S$ & $\begin{array}{l}\text { substrate (glucose, lactose or sucrose) concentra- } \\
\text { tion }(\mathrm{g} / \mathrm{L})\end{array}$ \\
\hline$S_{0}$ & $\begin{array}{l}\text { initial substrate (glucose or lactose) concentration } \\
(\mathrm{g} / \mathrm{L})\end{array}$ \\
\hline$X$ & biomass concentration $(\mathrm{g} / \mathrm{L})$ \\
\hline$X_{\max }$ & maximum concentration of biomass $(\mathrm{g} / \mathrm{L})$ \\
\hline$X_{0}$ & initial biomass concentration $(\mathrm{g} / \mathrm{L})$ \\
\hline$Y_{P / S}$ & $\begin{array}{l}\text { yield of biosurfactant production per substrate } \\
\text { consumption }(\mathrm{g} / \mathrm{g})\end{array}$ \\
\hline$Y_{P / X}$ & $\begin{array}{l}\text { yield of biosurfactant production per biomass } \\
\text { growth }(\mathrm{mg} / \mathrm{g})\end{array}$ \\
\hline$Y_{X / S}$ & $\begin{array}{l}\text { yield of biomass growth per substrate consump- } \\
\text { tion }(\mathrm{g} / \mathrm{g})\end{array}$ \\
\hline \multicolumn{2}{|c|}{ Greek letter } \\
\hline$\mu_{\max }$ & $\begin{array}{l}\text { maximum specific growth rate (ratio between ini- } \\
\text { tial volumetric rate of biomass formation }\left(r_{\mathrm{p}}\right) \text { and } \\
\text { initial biomass concentration } X_{0}\left(\mathrm{~h}^{-1}\right) \text { ) }\end{array}$ \\
\hline
\end{tabular}

that represents a major pollution problem for countries depending on dairy economics and is normally used as animal feed. Sophorolipids production using whey was reported by Otto et al. [11]. On the other hand, molasses is also an interesting alternative. Molasses is a by-product of the sugar cane industry and it has many applications because of its low price compared to other sources of sugar, and the presence of several other compounds besides sucrose. These include minerals, organic compounds and vitamins, which are valuable for the fermentation process $[20,21]$.

The aim of this study was to develop a low-cost alternative medium for biosurfactant production by L. lactis 53 and $S$. thermophilus A. Molasses and cheese whey were evaluated as alternative media and compared with the conventional synthetic medium. The yields of biosurfactant production for both strains were determined for all tested media. Additionally, the time courses of biosurfactant production, glucose, sucrose or lactose consumption and biomass growth were modelled.

\section{Materials and Methods}

\subsection{Microorganisms and inoculums}

The strains used in this work were L. lactis 53 and S. thermophilus A obtained from Nutricia (The Netherlands) and NIZO
(The Netherlands), respectively. The bacterial strains L. lactis 53 and S. thermophilus A were stored at $-20^{\circ} \mathrm{C}$ in conventional synthetic MRS or M17 broth (OXOID, Basingstoke, England), respectively. From frozen stock, bacteria were streaked on MRS or M17 agar plates and incubated at $37^{\circ} \mathrm{C}$ for further culturing. To prepare subcultures, the respective medium was inoculated with a colony from the plate and incubated overnight under the same conditions.

\subsection{Fermentation experiments}

To test biosurfactant production using alternative fermentation media, batch fermentations were carried out using the compositions described in Table 1. The conventional synthetic medium was prepared according to the supplier instructions (OXOID, Basingstoke, England). Appropriate dilutions were made in order to adjust lactose or sucrose initial concentrations of the medium. A 1-L bioreactor fitted with agitation control, as well as temperature and $\mathrm{pH}$ measurement and control were used. The temperature was maintained at $37^{\circ} \mathrm{C}$, the $\mathrm{pH}$ at 6.7 by automatic addition of a potassium hydroxide solution, and the agitation speed was set at $150 \mathrm{rpm}$. The total working volume was $0.5 \mathrm{~L}$.

\subsection{Cheese whey preparation}

Commercial whey supplied by Sigma-Aldrich contained $65 \%(\mathrm{w} / \mathrm{w})$ lactose and $11 \%(\mathrm{w} / \mathrm{w})$ protein and was prepared as follows: after adjusting the $\mathrm{pH}$ to 4.5 with $5 \mathrm{~N} \mathrm{HCl}$, it was heated at $121^{\circ} \mathrm{C}$ for $15 \mathrm{~min}$ to denature the proteins. The precipitates were removed by centrifugation at $4{ }^{\circ} \mathrm{C}$ and $8000 \times g$ for $10 \mathrm{~min}$. The supernatants were adjusted to $\mathrm{pH} 6.7$, sterilized at $121^{\circ} \mathrm{C}$ for $15 \mathrm{~min}$ and used as culture media. The supernatant contained approximately $50 \mathrm{~g} / \mathrm{L}$ of lactose. Yeast extract and peptone were added in suitable concentrations according to Table 1 . In previ-

Table 1

Medium compositions used in the fermentation experiments for both tested strains

\begin{tabular}{|c|c|}
\hline \multicolumn{2}{|c|}{ Medium } \\
\hline \multicolumn{2}{|c|}{ L. lactis 53} \\
\hline A & MRS broth \\
\hline $\mathrm{B}$ & W (50 g/L lactose content $)+3 \mathrm{~g} / \mathrm{L} \mathrm{YE}+5 \mathrm{~g} / \mathrm{L}$ PEP \\
\hline $\mathrm{C}$ & $\mathrm{W}(50 \mathrm{~g} / \mathrm{L}$ lactose content $)+3 \mathrm{~g} / \mathrm{L} \mathrm{YE}+10 \mathrm{~g} / \mathrm{L} \mathrm{PEP}$ \\
\hline $\mathrm{D}$ & $\mathrm{W}(50 \mathrm{~g} / \mathrm{L}$ lactose content $)+5.8 \mathrm{~g} / \mathrm{L} \mathrm{YE}+44.8 \mathrm{~g} / \mathrm{L} \mathrm{PEP}$ \\
\hline $\mathrm{E}$ & $\mathrm{M}(20 \mathrm{~g} / \mathrm{L}$ sucrose content $)+3 \mathrm{~g} / \mathrm{L} \mathrm{YE}+5 \mathrm{~g} / \mathrm{L} \mathrm{PEP}$ \\
\hline $\mathrm{F}$ & $\mathrm{M}(20 \mathrm{~g} / \mathrm{L}$ sucrose content $)+2.3 \mathrm{~g} / \mathrm{L} \mathrm{YE}+18 \mathrm{~g} / \mathrm{L} \mathrm{PEP}$ \\
\hline \multicolumn{2}{|c|}{ S. thermophilus A } \\
\hline $\mathrm{G}$ & M17 broth \\
\hline $\mathrm{H}$ & $\mathrm{W}(50 \mathrm{~g} / \mathrm{L}$ lactose content $)+3 \mathrm{~g} / \mathrm{L} \mathrm{YE}+5 \mathrm{~g} / \mathrm{L}$ PEP \\
\hline I & $\mathrm{W}(50 \mathrm{~g} / \mathrm{L}$ lactose content $)+3 \mathrm{~g} / \mathrm{L} \mathrm{YE}+10 \mathrm{~g} / \mathrm{L}$ PEP \\
\hline $\mathrm{J}$ & $\begin{array}{l}\mathrm{W}(50 \mathrm{~g} / \mathrm{L} \text { lactose content })+22 \mathrm{~g} / \mathrm{L} \quad \mathrm{YE}+43.8 \mathrm{~g} / \mathrm{L} \\
\mathrm{PEP}+231.6 \mathrm{~g} / \mathrm{L} \text { NGP }\end{array}$ \\
\hline $\mathrm{L}$ & $\mathrm{M}(20 \mathrm{~g} / \mathrm{L}$ sucrose content $)+3 \mathrm{~g} / \mathrm{L} \mathrm{YE}+5 \mathrm{~g} / \mathrm{L} \mathrm{PEP}$ \\
\hline M & $\begin{array}{l}\mathrm{M}(20 \mathrm{~g} / \mathrm{L} \text { sucrose content })+8.8 \mathrm{~g} / \mathrm{L} \quad \mathrm{YE}+17.5 \mathrm{~g} / \mathrm{L} \\
\mathrm{PEP}+92.6 \mathrm{~g} / \mathrm{L} \text { NGP }\end{array}$ \\
\hline
\end{tabular}

W, whey; YE, yeast extract; PEP, peptone; M, molasses; NGP, sodium glycerophosphate. 
ous published results [18] peptone and sodium glycerophosphate were found to be significant factors for biosurfactant production by L. lactis 53 and S. thermophilus A, respectively. Thus, proportions of yeast extract, peptone and sodium glycerophosphate used in media D, F, J and $\mathrm{M}$ were defined according to this previous study.

\subsection{Molasses preparation}

Molasses, by-product of the sugar cane industry, supplied by RAR (Porto, Portugal), contained 45\% (w/v) sucrose, $20 \%$ (w/v) fructose and $10 \%(\mathrm{w} / \mathrm{v})$ glucose. Molasses was diluted to a concentration of $20 \mathrm{~g} / \mathrm{L}$ sucrose and supplemented with yeast extract and peptone as described in Table 1 . The $\mathrm{pH}$ of the medium was adjusted to 6.7 prior to autoclaving $\left(15 \mathrm{~min}\right.$ at $\left.121^{\circ} \mathrm{C}\right)$.

\subsection{Bacterial growth determination}

Bacterial growth was measured by determining the optical density at $600 \mathrm{~nm}$ during different time intervals up to $30 \mathrm{~h}$. The biomass concentrations ( $g$ dry weight/L) were determined using a calibration curve. The calibration curve was calculated for each strain using dilutions of a biomass suspension with known optical density. A fixed volume of the dilutions was filtered $(0.22 \mu \mathrm{m})$ and left to dry at $105^{\circ} \mathrm{C}$ for $24 \mathrm{~h}$. All the filters were weighed before filtration and after drying. Thus, a relationship between biomass concentration $(\mathrm{g} / \mathrm{L})$ and optical density $(600 \mathrm{~nm})$ can be determined for each strain.

\subsection{Sugar analysis}

Sugar concentrations were determined by high performance liquid chromatography (Agilent, model 1100, Palo Alto, CA) using ION-300 column (Transgenomic Inc., San Jose, CA) with refractive index detector. The mobile phase was $0.01 \mathrm{~N} \mathrm{H}_{2} \mathrm{SO}_{4}$ at a flow rate of $0.4 \mathrm{~mL} / \mathrm{min}$.

\subsection{Surface activity determination}

The surface activity of biosurfactants produced by the bacterial strains was determined by measuring the surface tension of the broth samples by the Ring method [22] using a KRUSS Tensiometer equipped with a $1.9 \mathrm{~cm}$ De Noüy platinum ring at room temperature. To increase the accuracy an average of triplicates was used for this study.

\subsection{Evaluation of biosurfactant concentration}

The biosurfactant concentrations $(\mathrm{g} / \mathrm{L})$ were determined for each strain using a calibration curve (surface tension $(\mathrm{mN} / \mathrm{m})=-8.6465$ concentration $\left.(\mathrm{g} / \mathrm{L})+76.984, r^{2}=0.9729\right)$. The calibration curve was calculated for a commercial biosurfactant produced by several Bacilli (surfactin-lowers the surface tension of water to $27 \mathrm{mN} / \mathrm{m}$ at $5.0 \times 10^{-4} \mathrm{M}$ [23]) using different concentrations of biosurfactant solution, below the critical micelle concentration, with known surface tension. In this biosurfactant concentration range the decrease of surface tension is linear and it is possible to establish a relationship between the biosurfactant concentration and the surface tension [22,24]. Nevertheless, to estimate biosurfactant concentration it was necessary sometimes to dilute the culture broth under the critical micelle concentration.

Surfactin was used as a standard just like for example albumin is used as a standard in protein quantification assays, since it is one of the best studied biosurfactants and presents proteinaceous characteristics as the biosurfactants produced [25], thus providing a suitable method for estimating the biosurfactant concentration.

\subsection{Sugar consumption, biosurfactant production and biomass growth-fitting of data}

Experimental data were fitted to proposed models using commercial software (solver of Microsoft Excel 2002) by nonlinear regression using the least-squares method. Biosurfactant production was mathematically modelled following the equation proposed by Mercier et al. [26] for lactic acid production:

$\frac{\mathrm{d} P}{\mathrm{~d} t}=P_{\mathrm{r}} P\left(1-\frac{P}{P_{\max }}\right)$

where $t$ is the time (h), $P$ the biosurfactant concentration $(\mathrm{g} / \mathrm{L})$, $P_{\max }$ the maximum concentration of biosurfactant $(\mathrm{g} / \mathrm{L})$, and $P_{\mathrm{r}}$ is the ratio between the initial volumetric rate of product formation $\left(r_{\mathrm{p}}\right)$ and the initial product concentration $P_{0}(\mathrm{~g} / \mathrm{L})$. Eq. (1) can be directly solved to give Eq. (2):

$P=\frac{P_{0} P_{\max } \mathrm{e}^{P_{\mathrm{r}} t}}{P_{\max }-P_{0}+P_{0} \mathrm{e}^{P_{\mathrm{r}} t}}$

From the series of experimental data biosurfactant concentration/time, the model parameters $P_{0}, P_{\max }$, and $P_{\mathrm{r}}$ can be calculated for each strain growing in the several tested fermentation medium.

Also biomass production was mathematically modelled and can be interpreted by Eq. (3):

$X=\frac{X_{0} X_{\max } \mathrm{e}^{\mu_{\max } t}}{X_{\max }-X_{0}+X_{0} \mathrm{e}^{\mu_{\max } t}}$

where $t$ is the time $(\mathrm{h}), X$ the biomass concentration $(\mathrm{g} / \mathrm{L}), X_{\max }$ the maximum concentration of biomass $(\mathrm{g} / \mathrm{L})$, and $\mu_{\max }\left(\mathrm{h}^{-1}\right)$ is the ratio between the initial volumetric rate of biomass formation and the initial biomass concentration $X_{0}(\mathrm{~g} / \mathrm{L})$. The model parameters $X_{0}, X_{\max }$, and $\mu_{\max }$ can be calculated from the series of experimental data biomass concentration/time.

Sugar consumption can be interpreted by Eq. (4):

$S=S_{0}-\frac{1}{Y_{P / S}}\left(P-P_{0}\right)-\frac{1}{Y_{X / S}}\left(X-X_{0}\right)$

where $Y_{P / S}(\mathrm{~g} / \mathrm{g})$ and $Y_{X / S}(\mathrm{~g} / \mathrm{g})$ are the product yield for biosurfactant and biomass, respectively, $P$ and $P_{0}$ are the final and initial biosurfactant concentrations $(\mathrm{g} / \mathrm{L}), X$ and $X_{0}$ are the final and initial biomass concentrations $(\mathrm{g} / \mathrm{L})$, and finally $S_{0}$ is the initial glucose, lactose or sucrose concentration $(\mathrm{g} / \mathrm{L})$. The model parameters $Y_{P / S}, Y_{X / S}$ and $S_{0}(\mathrm{~g} / \mathrm{L})$ were calculated for each strain 


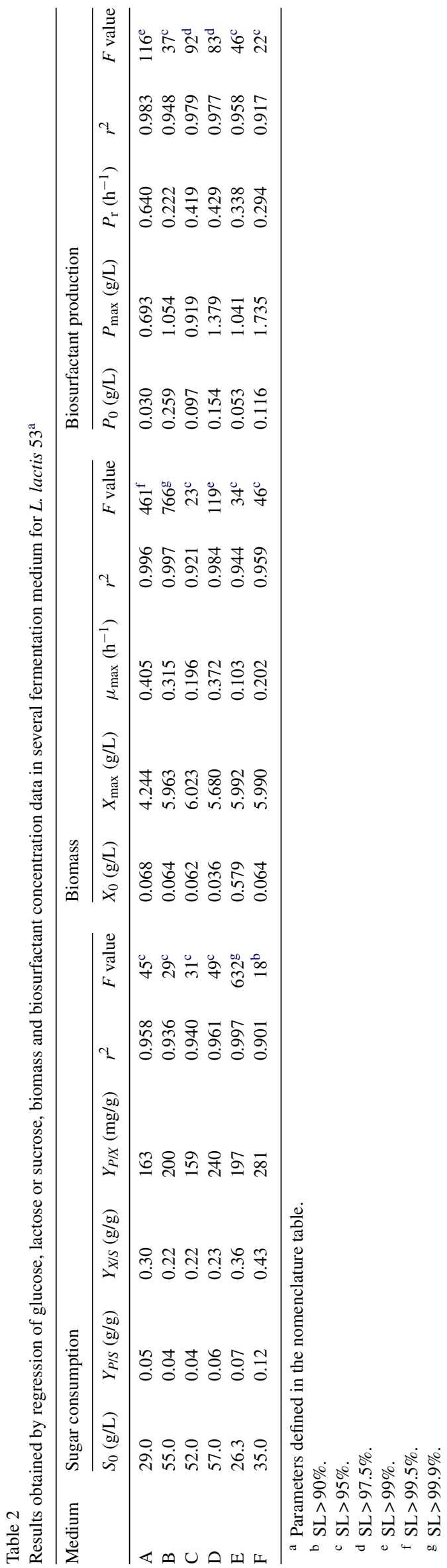

from the series of experimental data glucose, lactose or sucrose concentration/time and Eqs. (2) and (3).

The mathematical model proposed by Mercier et al. [26] was chosen because it fairly describes biomass growth, substrate consumption and product accumulation kinetic pattern, and is reasonable to predict that this mathematical model will adjust the biosurfactant production results with statistical significance of the parameters determined.

\section{Results}

\subsection{Biosurfactant production using conventional synthetic medium}

Fermentation control runs were carried out using the conventional synthetic medium MRS or M17 broth (A and G as defined in Table 1) for L. lactis 53 and S. thermophilus A, respectively. Experimental data were fitted to proposed models by nonlinear regression using the least-squares method. Tables 2 and 3 show the kinetic and regression parameters as well as the biosurfactant production yields. Both experiments show a kinetic pattern fairly described by the mathematical models with $r^{2}>0.952,0.996$ and 0.983 for glucose or lactose consumption, biomass growth and biosurfactant production, respectively. It can be noted that $S$. thermophilus A presents a higher $P_{\max }(0.8 \mathrm{~g}$ of biosurfactant $/ \mathrm{L})$ compared to L. lactis 53 ( $0.7 \mathrm{~g}$ of biosurfactant/L). Regarding the $Y_{P / S}$ both strains present the same value $(0.05 \mathrm{~g} / \mathrm{g})$. The $Y_{P / X}$ values listed in Tables 2 and 3 reflect the amount of biosurfactant produced $(\mathrm{mg})$ per amount of dry cells $(\mathrm{g})$. The $Y_{P / X}$ values obtained for both strains growing in control medium was 163 and $116 \mathrm{mg} / \mathrm{g}$ for L. lactis 53 and S. thermophilus A, respectively.

\subsection{Biosurfactant production using cheese whey}

Fermentations were carried out using whey supplemented with yeast extract and peptone as culture broth for both studied strains. Different sets of medium composition in yeast extract and peptone were evaluated. Figs. 1A and 2A show the experimental data as well as the predicted values calculated by Eqs. (2)-(4) using the regression parameters listed in Tables 2 and 3 for L. lactis 53 and S. thermophilus A growing in medium D and $\mathbf{J}$ (as defined in Table 1), respectively. For both strains growing in all the tested cheese whey medium (B-D, H-J as defined in Table 1), the experiments show a kinetic pattern reasonably described by the mathematical model with $r^{2}>0.936,0.921$ and 0.913 for lactose consumption, biomass growth and biosurfactant production, respectively. $P_{\max }$ values achieved with all cheese whey medium were higher than the observed for the control experiments. $P_{\max }$ values between 0.9 and $1.4 \mathrm{~g}$ of biosurfactant/L were obtained for both strains. Regarding the $P_{\mathrm{r}}$ the values obtained were between 0.22 and $0.429 \mathrm{~h}^{-1}$ for L. lactis 53, and between 0.078 and $0.725 \mathrm{~h}^{-1}$ for $S$. thermophilus A. Moreover, the $Y_{P / S}$ values obtained were similar for both strains and between 0.04 and $0.06 \mathrm{~g} / \mathrm{g}$, and $X_{\max }$ between 5.2 and $6.1 \mathrm{~g} / \mathrm{L}$ with a $\mu_{\max }$ between 0.196 and $0.447 \mathrm{~h}^{-1}$.

Comparing the kinetic parameters obtained with the cheese whey medium experiments and control, it was possible to notice 

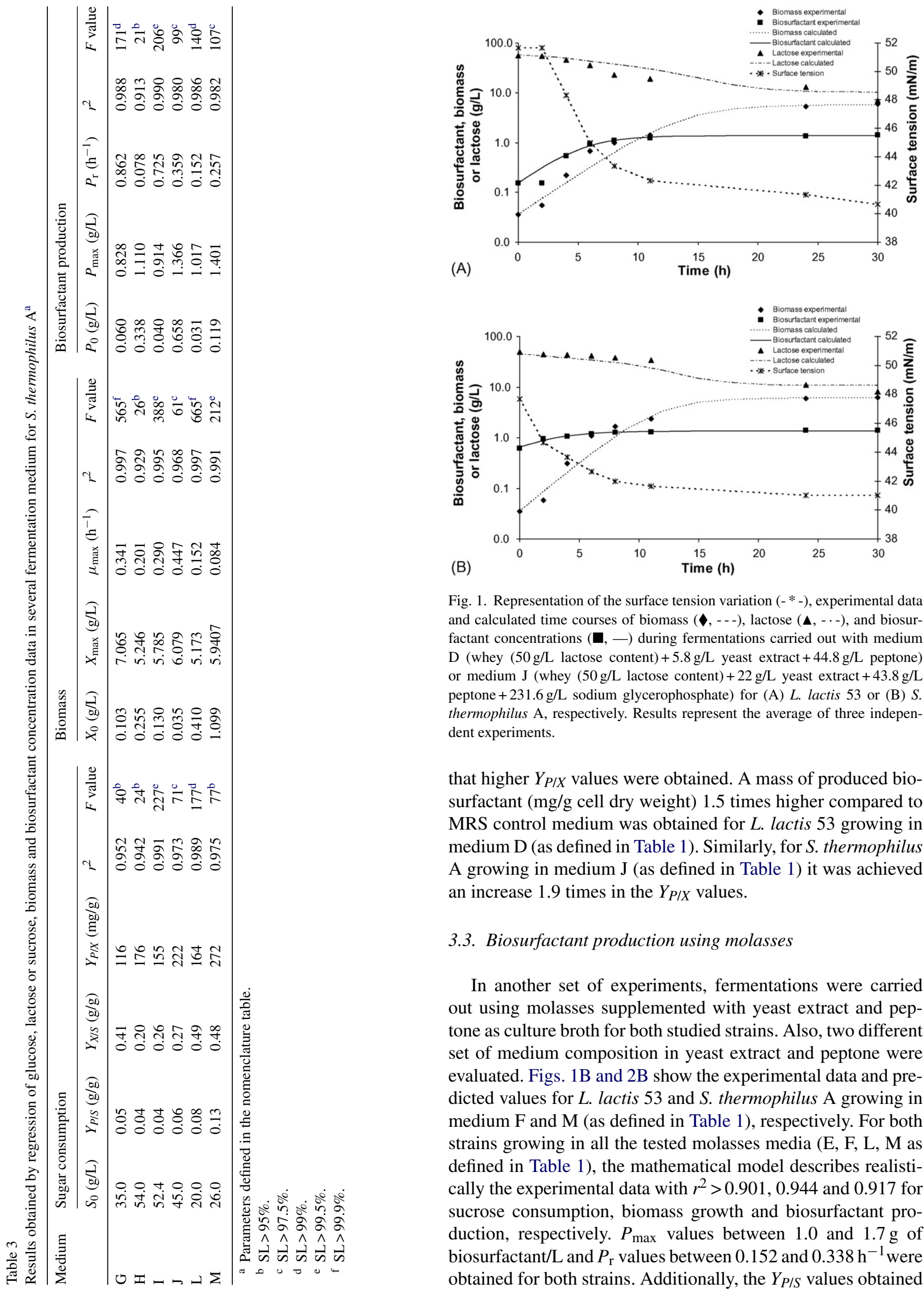

Fig. 1. Representation of the surface tension variation $\left(-*_{-}\right)$, experimental data and calculated time courses of biomass $(\boldsymbol{\bullet},--)$, lactose $(\boldsymbol{\Lambda}, \cdots)$, and biosurfactant concentrations $(\boldsymbol{\square},-)$ during fermentations carried out with medium $\mathrm{D}$ (whey $(50 \mathrm{~g} / \mathrm{L}$ lactose content $)+5.8 \mathrm{~g} / \mathrm{L}$ yeast extract $+44.8 \mathrm{~g} / \mathrm{L}$ peptone) or medium $\mathrm{J}$ (whey $(50 \mathrm{~g} / \mathrm{L}$ lactose content $)+22 \mathrm{~g} / \mathrm{L}$ yeast extract $+43.8 \mathrm{~g} / \mathrm{L}$ peptone $+231.6 \mathrm{~g} / \mathrm{L}$ sodium glycerophosphate) for (A) L. lactis 53 or (B) $S$. thermophilus A, respectively. Results represent the average of three independent experiments.

that higher $Y_{P / X}$ values were obtained. A mass of produced biosurfactant (mg/g cell dry weight) 1.5 times higher compared to MRS control medium was obtained for L. lactis 53 growing in medium D (as defined in Table 1). Similarly, for S. thermophilus A growing in medium $\mathrm{J}$ (as defined in Table 1) it was achieved an increase 1.9 times in the $Y_{P / X}$ values.

\subsection{Biosurfactant production using molasses}

In another set of experiments, fermentations were carried out using molasses supplemented with yeast extract and peptone as culture broth for both studied strains. Also, two different set of medium composition in yeast extract and peptone were evaluated. Figs. 1B and 2B show the experimental data and predicted values for L. lactis 53 and S. thermophilus A growing in medium F and M (as defined in Table 1), respectively. For both strains growing in all the tested molasses media (E, F, L, M as defined in Table 1), the mathematical model describes realistically the experimental data with $r^{2}>0.901,0.944$ and 0.917 for sucrose consumption, biomass growth and biosurfactant production, respectively. $P_{\max }$ values between 1.0 and $1.7 \mathrm{~g}$ of biosurfactant $/ \mathrm{L}$ and $P_{\mathrm{r}}$ values between 0.152 and $0.338 \mathrm{~h}^{-1}$ were obtained for both strains. Additionally, the $Y_{P / S}$ values obtained 

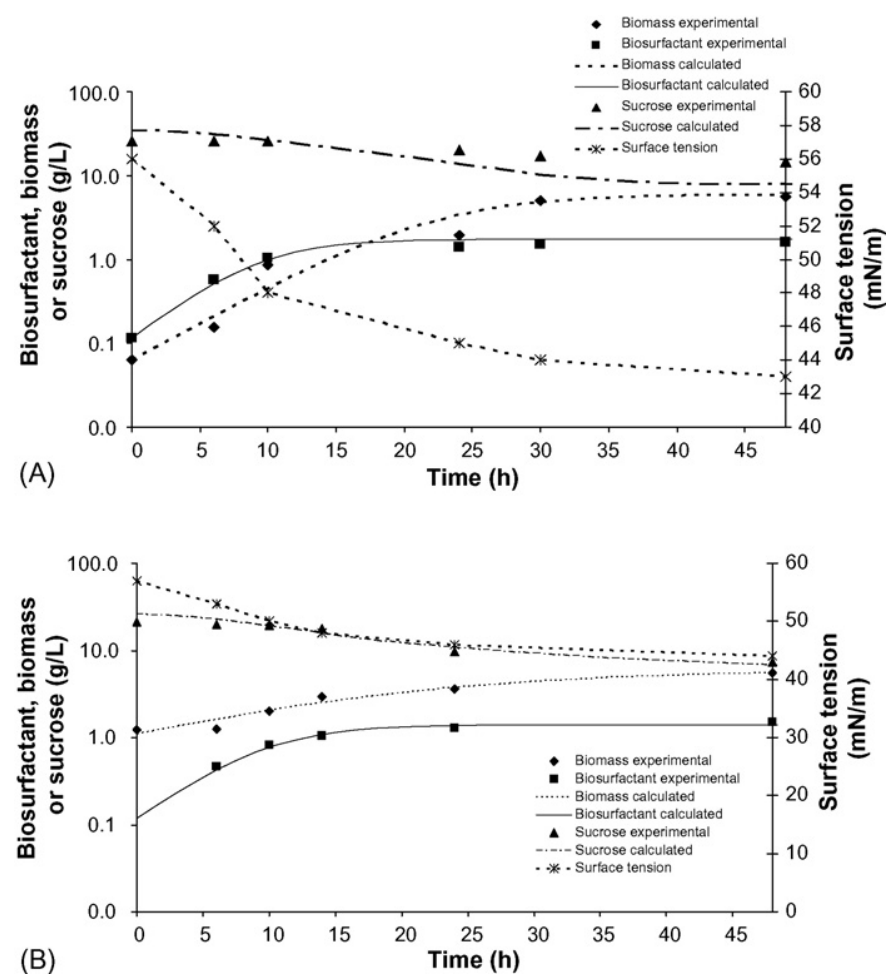

Fig. 2. Representation of the surface tension variation $\left(-*_{-}\right)$, experimental data and calculated time courses of biomass $(\downarrow,--)$, sucrose $(\boldsymbol{\Lambda}, \cdots)$ and biosurfactant concentrations $(\boldsymbol{\square},-)$ during fermentations carried out with medium $\mathrm{F}$ (molasses $(20 \mathrm{~g} / \mathrm{L}$ sucrose content $)+2.3 \mathrm{~g} / \mathrm{L}$ yeast extract $+18 \mathrm{~g} / \mathrm{L}$ peptone) or medium $\mathrm{M}$ (molasses $(20 \mathrm{~g} / \mathrm{L}$ sucrose content $)+8.8 \mathrm{~g} / \mathrm{L}$ yeast extract $+17.5 \mathrm{~g} / \mathrm{L}$ peptone $+92.6 \mathrm{~g} / \mathrm{L}$ sodium glycerophosphate) for (A) L. lactis 53 or (B) S. thermophilus A, respectively. Results represent the average of three independent experiments.

were similar for both strains and between 0.07 and $0.13 \mathrm{~g} / \mathrm{g}$, and $X_{\max }$ between 5.2 and $6.0 \mathrm{~g} / \mathrm{L}$ with a $\mu_{\max }$ between 0.08 and $0.202 \mathrm{~h}^{-1}$.

The higher $Y_{P / X}$ values were obtained for both strains compared whether to control or cheese whey medium experiments. A mass of produced biosurfactant (mg/g cell dry weight) 1.7 times higher compared to MRS control medium was obtained for L. lactis 53 growing in medium $\mathrm{F}$ (as defined in Table 1). Similarly, for S. thermophilus A growing in medium M (as defined in Table 1) it was achieved an increase 2.3 times in the $Y_{P / X}$ values.

\section{Discussion}

In this study we focused on the potential use of alternative fermentative medium formulations for biosurfactant production. For L. lactis 53 and S. thermophilus A, suitable models were established to describe the response of the experiments pertaining to glucose, lactose or sucrose consumption, cell growth and biosurfactant production. The models were validated by comparing the observed and predicted values, and a deviation of about $5 \%$ was found. The modelling procedure allowed a better characterization of the biosurfactant production by the determination of the fermentation parameters and it was observed a reasonable fitting with a significance level over $90 \%$.
The success of biosurfactant production depends on the development of cheaper processes and the use of low-cost raw materials, which account for $10-30 \%$ of the overall cost [6]. A great variety of agro-industrial wastes have been studied as potential substrates for biosurfactant production. Starch-rich wastes from potato-processing industries were successfully used for surfactant production [10]; molasses from sugar industry were assessed for biosurfactant production by Bacillus strains [20]; distillery and whey wastes were found to produce better results than conventional medium for rhamnolipid production $[27,28]$. Another good substrate for biosurfactant production is lactic whey, Daniel et al. [9] achieved production of high concentrations of sophorolipids from Candida bombicola ATCC 22214 and Cryptococcus curvatus ATCC 20509, using a two-stage fed batch process.

Whey is produced in large amounts by the cheese industry and is a huge waste disposal problem [29], being estimated a worldwide annual amount of about $4 \times 10^{7}$ tonnes. Cultivation of microorganisms on cheese whey has been proposed as an alternative to reduce waste disposal problem since it can reduce 90-95\% of its biochemical oxygen demand (BOD), resulting in high-added value bio-ingredients for food industry. Several studies have been reported on the use of cheese whey for lactic acid production [30-35]. Also, cheese whey was used for the production of dextran and fructose by Leuconostoc mesenteroides NRRL B512 (f) [36]; production of ethanol [37] and for the production of yeast extract by Kluyveromyces marxianus [29]. Hinted by a previous work [18] and the fact that probiotic bacteria, especially L. lactis 53 and S. thermophilus A, have been used for the production of biosurfactants [15-17,19,38-40], three different sets of medium conditions using cheese whey were tested to see their potentials for biosurfactant fermentation. In the present study it was achieved an increase about 1.5-1.9 times in the mass of produced biosurfactant per gram cell dry weight, for L. lactis 53 and S. thermophilus A, respectively. From the different proportions of yeast extract, peptone and sodium glycerophosphate supplemented to cheese whey it was possible to observe that the best results were achieved with the medium $\mathrm{D}$ $(50 \mathrm{~g} / \mathrm{L}$ lactose content, supplemented with $5.8 \mathrm{~g} / \mathrm{L}$ yeast extract and $44.8 \mathrm{~g} / \mathrm{L}$ peptone) for L. lactis 53 , and with the medium $\mathrm{J}$ $(50 \mathrm{~g} / \mathrm{L}$ lactose content, supplemented with $22 \mathrm{~g} / \mathrm{L}$ yeast extract, $43.8 \mathrm{~g} / \mathrm{L}$ peptone and $231.6 \mathrm{~g} / \mathrm{L}$ sodium glycerophosphate) for S. thermophilus A; which is in accordance with previous published results [18] where peptone and sodium glycerophosphate were found to be significant factors for biosurfactant production by L. lactis 53 and S. thermophilus A, respectively. Table 4 presents the costs of the ingredients used in the formulation of the fermentation medium, as well as the costs of the medium used in this study. Moreover, the presented information allowed the evaluation of the most economical medium formulations. Despite a higher biosurfactant production yield was achieved with medium D $(50 \mathrm{~g} / \mathrm{L}$ lactose content, supplemented with $5.8 \mathrm{~g} / \mathrm{L}$ yeast extract and $44.8 \mathrm{~g} / \mathrm{L}$ peptone) for $L$. lactis 53 , an increase of $40 \%$ in the medium preparation costs comparing with the synthetic MRS medium was estimated due to the high amounts of peptone supplemented; thus a compromise situation must be established to obtain higher biosurfactant production 
Table 4

Costs of the ingredients used in the formulation of fermentation medium

\begin{tabular}{lclr}
\hline Ingredient & Cost $(€ / \mathrm{kg})$ & Medium & Cost $(€ / \mathrm{L})$ \\
\hline Glucose & 0.4 & $\mathrm{~A}$ & 6.5 \\
Lactose & 0.4 & $\mathrm{~B}$ & 2.6 \\
Sucrose & 0.4 & $\mathrm{C}$ & 3.6 \\
Peptone & 202.5 & $\mathrm{D}$ & 10.8 \\
Yeast extract & 52.9 & $\mathrm{E}$ & 1.2 \\
Sodium glycerophosphate & 32.4 & $\mathrm{~F}$ & 3.8 \\
Whey & 27.88 & $\mathrm{G}$ & 6.5 \\
Molasses & 0.12 & $\mathrm{H}$ & 2.6 \\
& & $\mathrm{I}$ & 3.6 \\
& & $\mathrm{~J}$ & 18.9 \\
& & $\mathrm{~L}$ & 1.2 \\
\end{tabular}

yields with lower medium preparation costs. With medium B $(50 \mathrm{~g} / \mathrm{L}$ lactose content, supplemented with $3 \mathrm{~g} / \mathrm{L}$ yeast extract and $5 \mathrm{~g} / \mathrm{L}$ peptone) the mass of produced biosurfactant per gram cell dry weight increased 1.2 times with an estimated $60 \%$ decrease in the medium preparation costs comparing with the synthetic MRS medium. Similar conclusions were established for $S$. thermophilus A, where the use of medium H $(50 \mathrm{~g} / \mathrm{L}$ lactose content, supplemented with $3 \mathrm{~g} / \mathrm{L}$ yeast extract and $5 \mathrm{~g} / \mathrm{L}$ peptone) resulted in a biosurfactant production yield 1.5 times higher with an estimated $60 \%$ reduction in the medium preparation costs comparing with the synthetic M17 medium.

A by-product of the sugar cane industry, molasses, represents an alternative for the biosurfactant production process as it is a relatively inexpensive raw material compared to other substrate sources, and it possesses other valuable compounds for the fermentation process. This alternative medium was also studied in the present work for biosurfactant production by probiotic bacteria. The biosurfactant production yields achieved with supplemented molasses medium were higher than the obtained whether with conventional or supplemented cheese whey medium. Although higher amounts of biosurfactant were produced with medium F $(20 \mathrm{~g} / \mathrm{L}$ sucrose content, supplemented with $2.3 \mathrm{~g} / \mathrm{L}$ yeast extract and $18 \mathrm{~g} / \mathrm{L}$ peptone) and $\mathrm{M}(20 \mathrm{~g} / \mathrm{L}$ sucrose content, supplemented with $8.8 \mathrm{~g} / \mathrm{L}$ yeast extract, $17.5 \mathrm{~g} / \mathrm{L}$ peptone and $92.6 \mathrm{~g} / \mathrm{L}$ sodium glycerophosphate) for L. lactis 53 and S. thermophilus A, respectively; resembling what was observed for cheese whey medium, a better compromise between good yields and low-costs is achievable with medium where peptone and yeast extract amounts are lower ( $20 \mathrm{~g} / \mathrm{L}$ sucrose content, supplemented with $3 \mathrm{~g} / \mathrm{L}$ yeast extract and $5 \mathrm{~g} / \mathrm{L}$ peptone). Thus, an increase about 1.2-1.4 times in the mass of produced biosurfactant per gram cell dry weight and a $80 \%$ medium preparation costs reduction comparing with the synthetic MRS or M17 medium were achieved, for both strains.

Lactic acid bacteria ferment sugars via different pathways and are also capable of forming other products, e.g. flavours such as diacetyl and acetoin, bacteriocins or biosurfactants. The different carbon sources give varying amounts of by-products $[5,41]$. Hence, it can be speculated that the use of lactose or sucrose as carbon source instead of glucose induced the cells to use another metabolic pathway, and therefore the amount of mass of biosurfactant produced per gram cell dry weight varied. Lactic acid bacteria have already proven to be ideal hosts for metabolic engineering. The efficacy of metabolic engineering of lactic acid bacteria for the increased production of biosynthetic metabolites is yet to be demonstrated, but based on the results gathered in this study it seems to be an interesting approach for developing new strategies of biosurfactant production.

\section{Conclusions}

L. lactis 53 and S. thermophilus A showed a good performance for glucose or lactose to biosurfactant fermentation using the costly MRS or M17 broth, respectively, which includes among others yeast extract and peptone. When the conventional synthetic media were replaced by cheaper alternative media, as cheese whey heat precipitated and molasses, in all cases fermentations were carried out effectively with high yields and productivities of biosurfactant. The best results, even higher than those obtained with the conventional synthetic media, were obtained using supplemented molasses, thus it can be used as an alternative economical medium for biosurfactant production.

\section{Acknowledgment}

The FCT provided financial support for L.R. Rodrigues through a postdoctoral research grant SFRH/BPD/26064/2005.

\section{References}

[1] J. Desai, I. Banat, Microbial production of surfactants and their commercial potential, Microbiol. Mol. Biol. Rev. 61 (1997) 47-64.

[2] N. Kosaric, Biosurfactants in industry, J. Am. Oil Chem. Soc. 64 (1998) 1731-1737.

[3] S. Cameotra, R. Makkar, Synthesis of biosurfactants in extreme conditions, Appl. Microbiol. Biotechnol. 50 (1998) 520-529.

[4] T. Miller, B. Churchill, Substrates for large-scale fermentations, in: Manual of Industrial Microbiology and Biotechnology, American Society for Microbiology, Washington, DC, 1986, pp. 127-140.

[5] K. Hofvendahl, B. Hahn-Hägerdal, Factors affecting the fermentative lactic acid production from renewable resources, Enzyme Microb. Techonol. 26 (2000) 87-107.

[6] R. Makkar, S. Cameotra, An update on the use of unconventional substrates for biosurfactant production and their new applications, Appl. Microbiol. Biotechnol. 58 (2002) 428-434.

[7] V.K. Batish, R. Lal, H. Chander, Effect of nutritional factors on the production of antifungal substance by Lactococcus lactis subsp. lactis biovar diacetylactis, Aust. J. Dairy Technol. (1990) 74-76.

[8] P. Jensen, K. Hammer, Minimal requirements for exponential growth of Lactococcus lactis, Appl. Environ. Microbiol. 59 (1993) 4363-4366.

[9] H. Daniel, R.T. Otto, M. Binder, M. Reuss, C. Syldatk, Production of sophorolipids from whey: development of a two-stage process with Cryptococcus curvatus ATCC 20509 and Candida bombicola ATCC 22214 using deproteinized whey concentrates as substrates, Appl. Microbiol. Biotechnol. 51 (1999) 40-45.

[10] S. Fox, G. Bala, Production of surfactant from Bacillus subtilis ATCC 21332 using potato substrates, Bioresour. Technol. 75 (2000) 235240.

[11] R.T. Otto, H.J. Daniel, G. Pekin, K. Muller-Decker, Production of sophorolipids from whey II. Product composition, surface active properties, cytotoxicity and stability against hydrolases by enzymatic treatment, Appl. Microbiol. Biotechnol. 52 (1999) 495-501. 
[12] K.S. Rahman, T.J. Rahman, S. McClean, R. Marchant, I.M. Banat, Rhamnolipid biosurfactant production by strains of Pseudomonas aeruginosa using low-cost raw materials, Biotechnol. Prog. 18 (2002) 1277-1281.

[13] L.A. Sarrubo, A.L. Porto, G.M. Campos-Takaki, The use of babassu oil as substrate to produce bioemulsifiers by Candida lypolytica, Can. J. Microbiol. 45 (1999) 423-426.

[14] Q.-H. Zhou, N. Kosaric, Utilization of canola oil and lactose to produce biosurfactant with Candida bombicola, J. Am. Oil Chem. Soc. 72 (1995) $67-71$.

[15] L.R. Rodrigues, H.C. van der Mei, I.M. Banat, J.A. Teixeira, R. Oliveira, Inhibition of microbial adhesion to silicone rubber treated with biosurfactant from Streptococcus thermophilus A, FEMS Immun. Med. Microbiol. 46 (2006) 107-112.

[16] L.R. Rodrigues, H.C. van der Mei, J.A. Teixeira, R. Oliveira, Biosurfactant from Lactococcus lactis 53 inhibits microbial adhesion on silicone rubber, Appl. Microbiol. Biotechnol. 66 (2004) 306-311.

[17] L.R. Rodrigues, H.C. van der Mei, J.A. Teixeira, R. Oliveira, Influence of biosurfactants from probiotic bacteria on formation of biofilms on voice prosthesis, Appl. Environ. Microbiol. 70 (2004) 4408-4410.

[18] L.R. Rodrigues, J.A. Teixeira, R. Oliveira, H.C. van der Mei, Response surface optimization of the medium components for the production of biosurfactants by probiotic bacteria, Process Biochem. 41 (2006) $1-10$.

[19] L.R. Rodrigues, A. Moldes, J.A. Teixeira, R. Oliveira, Kinetic study of fermentative biosurfactant production by Lactobacillus strains, Biochem. Eng. J. 28 (2006) 109-116.

[20] R. Makkar, S. Cameotra, Utilization of molasses for biosurfactant production by two Bacillus strains at thermophilic conditions, J. Am. Oil Chem. Soc. 74 (1997) 887-889.

[21] R. Patel, A. Desai, Biosurfactant production by Pseudomonas aeruginosa GS3 from molasses, Lett. Appl. Microbiol. 25 (1997) 91-94.

[22] S. Kim, E. Lim, S. Lee, J. Lee, T. Lee, Purification and characterization of biosurfactants from Nocardia sp. L-417, Biotechnol. Appl. Biochem. 31 (2000) 249-253

[23] M. Morikawa, H. Daido, T. Takao, S. Murata, Y. Shimonishi, T. Imanaka, A new lipopeptide biosurfactant produced by Arthrobacter sp. strain MIS38, J. Bacteriol. 175 (1993) 6459-6466

[24] L.R. Rodrigues, A. Moldes, J.A. Teixeira, R. Oliveira, Kinetic study of fermentative biosurfactant production by Lactobacillus strains, Biochem. Eng. J. B 28 (2006) 109-116.

[25] L.R. Rodrigues, J.A. Teixeira, H.C. van de Mei, R. Oliveira, Physicochemical and functional characterization of a biosurfactant produced by Lactococcus lactis 53, Colloids Surf. B 49 (2006) 78-85.

[26] P. Mercier, L. Yerushalmi, D. Rouleau, D. Dochain, Kinetics of lactic acid fermentation on glucose and corn by Lactobacillus amylophilus, J. Chem. Technol. Biotechnol. 55 (1992) 111-121.
[27] K. Dubey, A. Juwarkar, Distillery and curd whey wastes as viable alternative sources for biosurfactant production, World J. Microbiol. Biotechnol. 17 (2001) 61-69.

[28] P. Sudhakar-Babu, A.N. Vaidya, A.S. Bal, R. Kapur, A. Juwarkar, P. Khanna, Kinetics of biosurfactant production by Pseudomonas aeruginosa strain BS2 from industrial wastes, Biotechnol. Lett. 18 (1996) 263-268.

[29] J.P. Palma Revillion, A. Brandelli, Z. Ayub, Production of yeast extract from whey using Kluyveromyces marxianus, Braz. Arch. Biol. Technol. 46 (2003) 121-127.

[30] A. Amrane, Y. Prigent, Growth and lactic acid production coupling for Lactobacillus helveticus cultivated on supplemented whey: influence of peptidic nitrogen deficiency, J. Biotechnol. 55 (1997) 1-8.

[31] A. Amrane, Batch cultures of supplemented whey permeate using Lactobacillus helveticus: unstructured model for biomass formation, substrate consumption and lactic acid production, Enzyme Microb. Techonol. 28 (2001) 827-834.

[32] G. Bustos, A. Moldes, J.L. Alonso, M. Vasquez, Optimization of D-lactic acid production by Lactobacillus coryniformis using response surface methodology, Food Microbiol. 21 (2004) 143-148.

[33] U. Kulozik, J. Wilde, Rapid lactic acid production at high cell concentrations in whey ultrafiltrate by Lactobacillus helveticus, Enzyme Microb. Techonol. 24 (1999) 297-302.

[34] S. Kwon, P. Lee, E. Lee, Y. Chang, N. Chang, Production of lactic acid by Lactobacillus rhamnosus with vitamin-supplemented soybean hydrolysate, Enzyme Microb. Techonol. 26 (2000) 209-215.

[35] S.J. Tellez-Luis, A. Moldes, M. Vasquez, J. Alonso, Optimization of lactic acid production by Lactobacillus delbrueckii through response surface methodology, J. Food Sci. 68 (2003) 1454-1458.

[36] M. Santos, A. Rodrigues, J.A. Teixeira, Production of dextran and fructose from carob pod extract and cheese whey by Leuconostoc mesenteroides NRRL B512(f), Biochem. Eng. J. 25 (2005) 1-6.

[37] L. Domingues, N. Lima, J.A. Teixeira, Alcohol production from cheese whey permeate using genetically modified flocculent yeast cells, Biotechnol. Bioeng. 72 (2001) 507-514.

[38] H.J. Busscher, T. Neu, H.C. Van der Mei, Biosurfactant production by thermophilic dairy streptococci, Appl. Microbiol. Biotechnol. 41 (1994) 4-7.

[39] G. Reid, C. Heinemann, M. Velraeds, H.C. van der Mei, H.J. Busscher, Biosurfactants produced by Lactobacillus, Meth. Enzymol. 310 (1999) 426-433.

[40] M. Velraeds, H.C. van der Mei, G. Reid, H.J. Busscher, Physicochemical and biochemical characterization of biosurfactants released by Lactobaillus strains, Colloids Surf. B Biointerfaces 8 (1996) 51-61.

[41] M. Kleerebezem, J. Hugenholtz, Lactic acid bacteria as a cell factory: rerouting of carbon metabolism in Lactococcus lactis by metabolic engineering, Enzyme Microb. Techonol. 26 (2000) 840-848. 